\title{
Articles
}

The Person and the Challenges

Volume 11 (2021) Number 1, p. 5-22

DOI: http://dx.doi.org/10.15633/pch.3882

Janusz Królikowski

ORCID: https://orcid.org/0000-0003-3929-6008

The Pontifical University of John Paul II in Kraków, Poland

\section{The Eucharist and the Holy Trinity. The liturgical aspect}

\begin{abstract}
Christian faith is based on the mystery of the Holy Trinity which, therefore, plays an indispensable role in the understanding of the particular truths of faith. This statement refers also to the Eucharist. The New Testament, especially the Gospel of John, conveys an explicit depiction of the links between the Holy Trinity and the Eucharist. The New Testament tradition has found its continuation in theology, and it has been predominantly seen in the Eucharistic Prayers. This paper highlights certain Trinitarian aspects of the mystery of the Eucharist, in order to point out further possibilities, both for deepening the understanding of this mystery and for more integral incorporation of it into faith and Christian experience.
\end{abstract}

\section{Keywords}

Eucharist, Holy Trinity, Eucharistic Prayer, epiclesis, doxology.

The best way to find the most complete explanation and the most accurate sense of the mysteries of Christian Faith is to juxtapose them with the most fundamental one, which is the mystery of the Most Holy Trinity - three divine Persons 
in one nature. Classical theological principles highlight that, the Trinitarian mystery constitutes the most appropriate interpretative criterion for particular truths of faith and the rule of critical verification of the results achieved by theology. The Eucharist is no exception in this respect, since in the light of the Holy Trinity it reaches complete religious and spiritual references and it gains the appropriate meaning in the life of the Church and of individual believers. Although the Eucharist manifests itself in the first place and essentially as a Christological mystery and not a Trinitarian one, its Christological and existential richness can be clearly visibly when it is coherently and completely situated in the perspective of the Trinitarian mystery. ${ }^{1}$ Links between the Holy Trinity and the Eucharist do not result from any kind of reverence or arbitrary presumptions, but they are rooted in the biblical revelation and they are consolidated in Church theology which systematised and deepened the biblical data. They are also widely and vividly expressed in the liturgy of the Church who, through liturgy, experiences and expresses her faith, and induces the believers into solemnities. In the broader meaning, it can be argued that generally "the theology of liturgy is the theology of the Holy Trinity."

In the everlasting course of life which is born from the Trinity and which in Trinity finds its historical fulfilment, within the frames of sacramental economy which realizes the appropriate way of its presentation to believers, at the present ecclesiastical stage of the history of salvation the Eucharist is the apogee of God giving us himself in His design to save man (cf. 1 Timothy 2:3). It is the sacrament of the communion with the Trinity in Jesus Christ. Via the Eucharist a radical "turn" in the Economy of Salvation takes place. Just as it has its source in the Trinity, the Eucharist constantly comes back to the Trinity. It is a gift from the Father, the redemptive presence of the Son and the sanctifying outpouring of the Holy Spirit. Mankind, united with Christ in the Eucharistic sacrifice and sanctified through the Spirit, returns to the Father and unites in the Trinitarian life.

${ }^{1}$ Dealing with the topic it is still good to refer to the classical work: M.-V. Bernadot, De l'Eucharistie à la Trinité, Paris 1919.

Cf. E. J. Kilmartin, Christian Liturgy: Theology and Practice. I. Systematic Theology of Liturgy, Kansas City 1988, pp. 100-123; S. Krajnc, Spirituality Based on the Liturgy and on the "Liturgy« through Liturgy, „Bogoslovni vestnik” Vol. 78 (2018), No. 3, pp. 797-811; I. Šaško, The Eucharist - the Summit in Accession, Permanency in Living the Initiation, "Bogoslovska Smotra" Vol. 79 (2009) No. 3, pp. 523-536; I. Raguž, Trinitarian-Eucharist Thinking about Christian Initiation, "Bogoslovska Smotra" Vol. 79 (2009) No. 3, pp. 537-561. 
The Second Vatican Council expressed synthetically all these biblical and theological ideas in the decree Unitatis redintegratio, at the same time directing the present Eucharistic theology towards the Trinity. The decree reads that via the Eucharist: "The faithful, united with their bishop, have access to God the Father through the Son, the Word made flesh, Who suffered and has been glorified, and so, in the outpouring of the Holy Spirit, they enter into communion with the most Holy Trinity, being made «sharers of the divine nature» (2 Peter 1:4)" (No. 15). Unfortunately, in the Eucharistic context this universalistic theological perspective has not been appreciated enough and it has not been broadly introduced yet into the renewed Eucharistic doctrine. That is why, in this paper we intend to highlight this significant issue which, properly explored, may contribute to the revival of both theology and Eucharistic celebration, and especially to the integration of the Eucharist with the Christian profession of faith in order to point out the mutual bonds that exist between the Eucharist and the entire Christian faith. By the same token, we seek to emphasise even stronger the central position of the Eucharist in the life of the Church, according to the teaching of the Second Vatican Council, and indirectly, also in theology.

\section{The Eucharist and the Holy Trinity in the light of the New Testament}

The gradual revelation of the Holy Trinity, broadly depicted in the Gospel of John, explicitly outlines the fundamental Trinitarian scheme of Christian faith $^{3}$ which, in the same Gospel, overlaps with the concurrent development of the Eucharistic scheme which would ultimately become a revelation of the mystery of the Eucharist. Certainly, this fact deserves more attention in the context of Eucharistic theology.

The discourse on the bread of life, in the Gospel of John (6:26-71), develops in the way that it gradually reveals its supreme goal, which is the Eucharist presented at the background of the glorious events from the history of salvation. ${ }^{4}$ Jesus' speech is at the same time historical and theological in character.

${ }^{3}$ Cf. G. Ferraro, Il Paraclito, Cristo, il Padre nel quarto Vangelo, Città del Vaticano 1996.

${ }^{4}$ Cf. H. Schlier, La fine del tempo, Brescia 1971, pp. 115-139; S. Mędala, Chrystologia Ewangelii św. Jana, Kraków 2001, pp. 319-323; X. Léon-Dufour, Il Pane della vita, Bologna 2006, pp. 97-110. 
It includes Christ's words and personal reflections of His disciple, and it evokes outstanding theological ideas of his Gospel, especially those which clearly appear in the prologue. They are all specifically combined in the mystery of the Eucharist which manifests itself in this way as the extension and fulfilment of the incarnation.

At the onset of the saving process which is fulfilled in the Eucharist, there is God the Father who provides the faithful with the true bread of life: "it is my Father who gives you the true bread from heaven" (John 6:32). The Father brings the faithful closer to the understanding of this mystery, leading them spiritually: "No one can come to me unless drawn by the Father who sent me" (John 6:44). Finally, it is the Father who provides the faithful with the only Trinitarian life through Christ who becomes Himself the bread of life for the faithful: "As the living Father sent me and I draw life from the Father, so whoever eats me will also draw life from me" (John 6:57).

The role of the Father in the Eucharist appears to be primary, but also permanent and ultimate. The bread of life comes from the Father; it is His gift in which He grants the faithful His Divine and everlasting life, by the agency of His Only-begotten Son. Undoubtedly, it is an example of the definite primacy of the Father which has already been highlighted in John's prologue, in which the Word-Son coming into the world is shown as an everlasting "reflection" of the Father, being His everlasting "Agent": "the Word was with God" (John 1:1). The everlasting Word receives everything from the Father, and through the Word all that is in the Father by the mercy of God may be given to all people. The bread of life constitutes the particular realization of this fact showing that it is fulfilled in reference to each and every believer who eats this bread.

Christ Himself is the bread of life. St. John expresses this fact in an exceptionally realistic way: "I am the bread of life. [...] I am the living bread which has come down from heaven. The bread that I shall give is my flesh, for the life of the world" (John 6:48,51). The accomplishment of these statements from the Gospel of John are the words describing the institution of the Eucharist conveyed by the Synoptic Gospels: "This is my Body, which is given for you" (Luke 22:19); "This cup is the New Covenant in my Blood poured out for you" (Luke 22:20).

The words "body" and "blood" in the biblical language of the Old Testament, to which St. John clearly refers, point out to a living and active reality, namely that these words are used for the purpose of portraying a real human. ${ }^{5}$ The words

${ }^{5}$ Cf. H. W. Wolff, Antropologia dell'Antico Testamento, Brescia 1993, pp. 40-47. 
of Christ explicitly reflect this specific language: He is the bread of life - His person. The revelation of the appropriate content of the mystery of the Eucharist is summarised in His God-man "I": "Whoever eats Me, will also draw life from Me" (John 6:57).

Therefore, the gift from the Father is His Son who remains in the closest relation with all the saving mysteries realized in and through His humanity. The Eucharist extends the mystery of the Word made flesh sacramentally, and performs it by situating itself in the same redemptive perspective which was applied to express the mystery of the incarnation. ${ }^{6}$ Furthermore, the Eucharist does so on the basis of the same realism which was applied to express the mystery of the "Word which became flesh" (John 1:14). In the same way in which the Word became flesh, now in the same flesh, it becomes food for man. Christ offers himself to believers in the act of His sacrifice which is symbolized by the broken bread and shed blood, described and elucidated in His words. It has been preserved in a remembrance which is continually "done" by the Church according to Christ's will (cf. Luke 22:19) realizing in time and space the only, definite and everlasting sign of Christ's sacrificial love. The Eucharistic presence is however the paschal presence, that is the presence of the Risen Lord present among His believers as a Priest "who has gone through to the highest heaven" (Hebrews 4:14), sits at the table together with His believers, as He did after the resurrection when He sat for the meal with His disciples in his humanity bearing the evidence of the Passion and glory, with the glorious signs of His victory and the presence of the Holy Spirit acting in Him.

If Jesus Christ is the very gift of the Father, then the communion with His humanity fills the believers with His Spirit. Biblical references to the gift of the Spirit are actually scarce in this matter, but they are unquestionable, hence they are sufficient to formulate the Eucharistic doctrine which is more open to the Holy Spirit. During the Eucharistic speech Jesus says: "It is the Spirit that gives life, the flesh has nothing to offer" (John 6:63) This statement means that the Spirit, who fills Christ's glorious humanity, makes his flesh capable of transferring the life of God. This concise sentence reflects the whole theology of St. John, referring to the outpouring of the Spirit by Christ's humanity, which stays in close relation to the synoptic tradition and the theology of St. Paul. Furthermore,

\footnotetext{
${ }^{6}$ A broad commentary dealing with this issue can be found in: P. L. Carle, Le sacrifice de la Nouvelle Alliance. Consubstantiel et transubstantiation. De l'Incarnation à l'Eucharistie, Bordeaux 1981.
} 
the passage describing the institution of the Eucharist refers indirectly to the gift of the Spirit. The Eucharist is the Blood of the Covenant which seals new relations between God and people. Whereas, the significant gift of the New Covenant, foreshadowed by the prophets and historically fulfilled in the Eucharist, is the outpouring of the Spirit in the hearts of the faithful (cf. Jeremiah 31:31-33; Ezekiel 36:25-27). ${ }^{\text {? }}$

The same idea can be found in the teachings of St. Paul who presents the Eucharist as the sacrament - the sign and the cause - of Church unity (cf. 1 Corinthians 10:17). ${ }^{8}$ Only Christ's Spirit may realize the proper, internal unity of the faithful and their spiritual growth in Christ. As in many other instances, according to the tradition form earliest tradition about the Holy Spirit, we speak here about the Holy Spirit relying on the results brought about by His working in the Church.

The revelation of the Eucharist that can be found especially in the Gospel of John includes explicit and complete Trinitarian references. They point out not only to its source, but also to its spiritual significance - remaining of man in the Trinity - and its goal which is the everlasting Trinitarian communion: "Anyone who eats this bread will live for ever" (John 6:58). The Father is the source, Christ is the gift, and the Holy Spirit is the ultimate saving reality as a simultaneous gift of Father and Son. In its internal effect - on the basis of eating and drinking - this divine gift becomes a bond of love between the Trinity and humanity. The same life of God, which has its source in the Father and is outpoured in the faithful via the Holy Spirit, goes through the humanity of Jesus Christ, whose redemptive function is mostly revealed in the mysteries of His life. This is how the singularity of the life of God is revealed with the concurrent diversity of its aspects in reference to the particular Divine persons. A Christian unites with the Father who is the source of grace, with the Son who is the Maker of salvation and, with the Holy Spirit who is the Sanctifier of the entire Church and every single soul belonging to her.

${ }^{7}$ Cf. A. Jankowski, Biblijna Teologia przymierza, Kraków 1997, pp. 105-123.

${ }^{8}$ Cf. The Second Vatican Council, Constitution Lumen gentium, 11: "[The faithful] strengthened in Holy Communion by the Body of Christ, they then manifest in a concrete way that unity of the people of God which is suitably signified and wondrously brought about by this most August Sacrament". 


\section{The systematic aspect}

In Eucharistic theology, especially in the West, for ecclesial and cultural reasons the deepening of the data revealed in the systematic Eucharistic theology was concentrated on Christ's presence in the Eucharist. After the Second Vatican Council, the doctrinal revival brought about the wider study in this field within the frames of Eucharistic theology, and made an effort to develop the subject of the presence in the context of a sacrifice, remembrance, feast, and gathering, that is within the liturgical aspect. The conciliar doctrine, developed later in numerous post-conciliar documents, brings new effects also responding to the emerging difficulties and controversies. Somehow, the traditional doctrine of the presence found itself in a critical situation, mainly in reference to the formulas in which it is expressed but also in relation to the present mentality. Pope Paul VI, in the encyclical letter Mysteriumfidei, undertook these challenges remarkably well and made a valuable contribution to the theological reflection on the real presence of Christ in the Eucharist.

In the light of the aforementioned biblical data, it can be argued that a perspective which is too unilateral a perspective on the mystery of the Eucharist, namely as seen only in the Christological sense, even if it is correct, is insufficient to present it in a holistic way. Contemporary theology, after combining different vital aspects of faith with the mystery of the Eucharist (sacrifice, remembrance, feast), opens new perspectives in the direction of its Trinitarian dimension from the dogmatic point of view - and in the direction of the existential dimension, especially from the spiritual point of view. Basically, these two points converge upon the relations existing between the Eucharist and the Holy Spirit. ${ }^{9}$ Especially significant issues refer, in this case, to the working of the Holy Spirit in the Eucharistic gifts and to the sacramental grace of the Eucharist as a spiritual communion with Christ through the gift of His Spirit. These two issues originate directly from the Revelation, have been broadly developed especially in eastern theology ${ }^{10}$ and, are also accepted by non-Catholic Christians.

${ }^{9}$ Cf. J. M. R. Tillard, L'Eucharistie et le Saint-Esprit, „Nouvelle Revue Théologique” 100 (1968), pp. 363-387; D. Valentini, Lo Spirito Santo. La Chiesa e l'uomo. Studi di ecclesiologia e di ecuemnismo, Roma 2017, pp. 31-42.

${ }^{10}$ Cf. B. Bobrinskoy, Communion du Saint-Esprit, Abbaye de Bellefontaine 1992, pp. 93-101. 


\section{The working of the Holy Spirit}

One of the most characteristic elements of eastern theology and liturgy is a direct attribution of the occurring transubstantiation of the Eucharistic gifts to the almighty and mysterious working of the Holy Spirit. ${ }^{11}$ This is the sense of the epiclesis, that is the prayer directed to the Father so that He sends the Holy Spirit in order to sanctify and change bread and wine. ${ }^{12}$ This Church recognition is reflected in manifold ancient liturgical texts and mystagogical catechesis. Let us take a look at two of them.

In the anaphora of St. John Chrysostom the following epiclesis can be found: "Moreover, we offer to you this spiritual and unbloody sacrifice; and we implore, pray, and entreat you: send down your Holy Spirit upon us and upon these gifts lying before us, And make this bread the precious body of your Christ, and that which is in this chalice the precious blood of your Christ, changing them by your Holy Spirit, that for those who partake of them they may bring about a spirit of vigilance, the remission of sins, the communion of your Holy Spirit, the fullness of the heavenly kingdom, and confidence in you, not judgment or condemnation."13

In the catechesis on the Holy Mass, St. Cyril of Jerusalem teaches as follows: "Then having sanctified ourselves by these spiritual Hymns, we beseech the merciful God to send forth His Holy Spirit upon the gifts lying before Him; that He may make the Bread the Body of Christ, and the Wine the Blood of Christ; for whatsoever the Holy Ghost has touched, is surely sanctified and changed."14

The references to the changing action of the Holy Spirit are really frequently found in eastern Eucharistic theology and they find their apex in the anaphora of St. Basil. ${ }^{15}$ On the other hand, in western theology it appears quite occasionally and rather indirectly. Roman Liturgy altogether with the Roman Canon is actually silent about this subject, limiting itself only to certain imagery with

${ }^{11}$ This issue is clearly visible in the so called "dispute about the epiclesis".Cf. J. Klinger, Genezasporu o epiklezę. Eschatologiczny a memorialny aspekt Eucharystii w kanonie pierwszych wieków, Warszawa 1969.

${ }^{12}$ When the biblical foundations of the epiclesis are concerned, cf. L. Alonso Schökel, L'Eucaristia, Milano 1988, pp. 75-88.

${ }^{3}$ Wieczerza Mistyczna. Anafory eucharystyczne chrześcijańskiego Wschodu, selection, introduction, translation and footnotes, H. Paprocki, Warszawa 1988, pp. 127-128.

${ }^{14}$ Saint Cyril of Jerusalem, Catechetical lecture 23 (on the Mysteries. V.), 7.

${ }^{15}$ Cf. C. Giraudo, Eucaristia per la Chiesa. Prospettive teologiche sulleucaristia a partire della «lex orandi», Roma-Brescia 1989, pp. 436-443. 
pneumatological meaning, like for example extending hands over the gifts. In the profession of faith designed for Waldensians there is a mention of the Eucharistic sacrifice, namely that it is brought about "through the word of the Creator and through the power of the Holy Spirit - in verboefficitur Creatoris et in virtute Spiritus Sancti." ${ }^{316}$ St. Thomas Aquinas, in his Eucharistic theology, points out only that the Body of Christ is present in the sacrament spiritually, that is in an invisible way thanks to the causative power of the Spirit. ${ }^{17}$ In the recent decades, the liturgical reform together with Eucharistic prayers and Church documents opened a broader perspective in this respect, although they are not always consequently applied..$^{18}$ It has to be noted as well that Protestant theology, especially Calvinist one, is very sensitive in this respect. Additionally, numerous ecumenical documents regarding the Eucharist also contribute to the significance of this issue. ${ }^{19}$

The idea of the participation of the Holy Spirit in the transubstantiation, expressed with an exceptional lyricism in the liturgies of the East, has its origin in two fundamental theological principles clearly visible in the Old Testament. First of all, it has its source in the essential relations existing between the Holy Spirit and Christ's humanity, emphasised by the Evangelists in the pivotal moments of His life: incarnation by the agency of the Holy Spirit (cf. Luke 1:31), anointing with the Spirit for proclaiming the kingdom of God (cf. Mathew 3:17; Acts of Apostles 10:37-38), glorious resurrection by the power of the Spirit (cf. Genesis 1:3; 8:11). The Eucharist, in which via the miraculous change of bread and wine the wondrous humanity of Jesus Christ is manifested, situates itself on the soteriological line of the miraculous exchange taking place in the incarnate Word through the Holy Spirit. There is another principle that can be derived from the facts above. It finds its expression in the conviction emphasised by Church Fathers according to which all that is miraculously realized by God in the act of creation and in the New Covenant is brought about by the agency of the Spirit of the Lord. This conviction was already applied in the decree of the Council of Trenton the Most Holy Sacrament, in which it is unequivocally stated

${ }^{16}$ Innocent II, Letter Eius exemplo (December 18, 1208.), DH 794.

${ }^{17}$ Cf. St. Thomas Aquinas, Summa theologiae III q. 75 a. 1 ad 1.

${ }^{18}$ Cf. A. Triacca, Lo Spirito Santo nella liturgia e nella vita della Chiesa, Città del Vaticano 2011, pp. 105-135.

${ }^{19}$ Cf. Z. Glaeser, Eucharystia jako wydarzenie w jedności Ducha Świętego, in: Wspólna Eucharystia - cel ekumenii, ed. P. Jaskóła, R. Porada, Opole 2005, pp. 253-264 (Ekumenizm i Integracja, 12). 
that transubstantiation is "the singular and wonderful conversion - mirabilis et singularis conversion." ${ }^{20}$ The singularity and wonder of the transubstantiation should be associated with the divine works of the Holy Spirit. Therefore, it can be argued that these words are the evidence of the openness of the Tridentine doctrine to the completion by the Holy Spirit, although it was not mentioned in the post-Tridentine theology which concentrated its interpretations mostly on the meaning of the words of the priest (vi verborum), unilaterally ascribing to them the sacramental effectiveness. ${ }^{21}$

That is why we can claim, that the Holy Spirit is the one who sanctifies the Eucharistic gifts, fills them with His power and performs the transformation into the Body and Blood of Christ. These conclusions are essential in the context of the current reflection on the mystery of the Eucharist, especially on the issue of the presence and its ecclesial and spiritual influence. If the tradition accepts the extraordinary and wonderful work of the Holy Spirit in the transubstantiation of the gifts, then it means, among other things, that it occurs at the innermost level of being and, for that reason, all the attempts at approaching the Eucharistic conversion only at a functional, superficial or symbolic level are absolutely incongruous. The Holy Spirit, with the divine power, brings about an internal, singular and marvellous change of bread and wine conferring a totally new content on them and endows them with a completely new effectiveness. By virtue of which the Eucharist, when consumed, enables man to transcend the circumstances of this life as a result of the ultimate communion with God. Therefore, on the basis of the workings of the Holy Spirit in the Eucharist, we can speak about the Eucharist as an anticipation and the pledge of eternal life. ${ }^{22}$

\section{The outpouring of the Holy Spirit}

The Eucharist, according to the Second Vatican Council, is Christ Himself, "our Pasch and Living Bread, by the action of the Holy Spirit through his very flesh vital and vitalizing, giving life to men." ${ }^{23}$ Christ's humanity, present in the

${ }^{20}$ The Council of Trent, Decree touching the Most Holy Sacrament of the Eucharist, can.2: DH 1652.

${ }^{21}$ The Council of Trent, Decree touching the Most Holy Sacrament of the Eucharist, can. 3: DH 1640.

${ }^{22}$ Cf. R. E. Rogowski, Światłość i tajemnica. Z problematyki teologii egzystencjalnej, Katowice 1986, pp. 316-327.

${ }^{23}$ The Second Vatican Council, Decree: Presbyterorum ordinis, 5. 
Eucharist, is glorious and spiritual, that is "filled with the Spirit". The Holy Spirit is a gift from the risen Christ for His believers so that they could surely and finally achieve everything that He earned for them. The bestowing of the Spirit of the Sanctifier is realized in the eucharistic communion precisely for this reason and that is its actual goal. The doctrine, included for example in the post-conciliar instruction Eucharisticum mysterium (25 May 1967), should be interpreted in this perspective: "But union with Christ, to which the sacrament itself is directed, is not to be limited to the duration of the celebration of the Eucharist; it is to be prolonged into the entire Christian life, in such a way that the Christian faithful, contemplating unceasingly the gift they have received, may make their life a continual thanksgiving under the guidance of the Holy Spirit and may produce fruits of greater charity" (No. 38).

That is also the direction of the contemporary Eucharistic theology which shifts the emphasis from the sacramental presence of Christ to sacramental grace which is the communion with Him and with all the members of the mystical Body by the action of the Holy Spirit. St. Augustine already pointed out that this communion is realized in the most absolute sense "usquead Spiritus participationem Spiritus manducemus et bibimus", namely to the very participation in the same Spirit. ${ }^{24}$ Christ's salvific interaction with man is prolonged in the process of sanctification, mutual transcendence and internal assimilation which, in the Economy of Salvation, is the work of the Spirit of the Lord. This is where the whole orientation of the modern Eucharistic spirituality is born, directed not any more to adoration of the present Christ, but rather to the communion with Him via the Holy Spirit at each and every moment of life, to the meeting with neighbours on the plane of religious and everyday life, and to the practicing of brotherly charity inspired and shaped by the Spirit of love (cf. Romans 5:5).

These principles extend the eucharistic theology and clearly combine it with the mystery of the Holy Trinity and coincidently, it gains a broader and more vital meaning. The mystery of salvation, which has its origin in the Father and reaches us thanks to Christ's work, is fulfilled in the bestowing of the Holy Spirit. Consequently, the Eucharist is the most direct manifestation of this mystery and it provides the real and fullest participation in it.

${ }^{24}$ St. Augustine, In Ioannis Evangelium tractatus 27, 11. 


\section{The Trinitarian sense of the Eucharistic Prayers}

The liturgy summarises in its prayers the biblical data and the results of theological reflection, concurrently revealing the dynamism of the Eucharistic mystery in the light of the Holy Trinity. Modern theology, following Karl Rahner ${ }^{25}$, has frequently drawn the attention to the lack of the proper theological sensitivity to the fact that the Eucharistic offering is sacrificed in the same way to all three persons of the Trinity. Cursory reading of the Eucharistic prayers is enough to discover the appropriate Trinitarian "rhythm" of the Eucharist closely connected to the most authentic understanding of the Trinitarian economy of salvation. This Trinitarian rhythm is expressed in various contents gathered in the Eucharistic prayers, so as to find its culmination in the solemn final doxology. The Eucharistic Prayers are the expression of the awareness of the global faith of the Church: they are addressed to the Father through Christ in the Holy Spirit; they express Christ's sacrifice to the Father through the ministry of the Church who is led by the Holy Spirit. This offering is met not only with the acceptance of the sacrifice, but it goes together with the real gift from the Father in the presence of His Son along with the outpouring of the Holy Spirit. It is worth noticing that, certain dominant aspects of this faith are included in the Eucharistic Prayers.

\section{To the Father}

The Prayer of the Church, from the beginning to the end, according to the most traditional beliefs of the Church is consistently addressed to the Father. The Church prays with Christ and in His name, uniting itself especially with His filial relationship with the Father, which was expressed in the highest form in His prayer addressed to the Father. This fact is clearly and solemnly emphasised in the Eucharistic prayers starting from the prefaces including the recurring phrases: "Father most holy", "Heavenly Father". The Roman Canon opens with a dignified and respectful acclamation: "Most merciful Father" which is crowned with the passage in the doxology: "O God, almighty Father". During this prayer these acclamations are supplemented with other prayers: "Almighty Father", "most merciful Father", "our Lord". Other Eucharistic Prayers complete these

${ }^{25}$ Cf. K. Rahner, Bemerkungen zum dogmatischen Traktat «De Trinitate», in: Schriften zur Theologie, vol. 4: Neuere Schriften, Einsiedeln-Zürich-Köln 1964, p. 107. 
acclamations and strengthen some of them, especially by the usage of the acclamation: "most holy Father". Thus, Jesus's prayer as the son, which constitutes the supreme example and standard of the prayer for the Church, emphasises and simultaneously confirms that the Father is the source and purpose of everything. During Mass the Father is presented especially as a source and purpose of the saving sacrifice of Jesus Christ; the Church brings praise and thanksgiving to God the Father, receiving the blessing and the presence of the Son from Him.

\section{Through the Son}

The figure of Christ in the Eucharistic prayer is slightly indistinct. His voice and His offering are intermingled with the voice and offering of the Church. Furthermore, His picture as a Mediator is not very distinct in Eucharistic prayers; it is mostly visible when the liturgy refers to His everlasting mediation: "Through Jesus Christ...", “Through your Son.... However, this picture remains a vital element which stands out as an original principle of the Eucharistic celebration and makes sense only in the light of Christ's mediator ship reaching its cultic apogee, at the same time achieving certain salvific effectiveness. His invisible presence in the Church through and in the sacred gifts, becomes discernible, specific and defined; it is His glorious humanity - Body and Blood - brought before the Father as an offering of adoration and atonement, and now given to the faithful as the food and drink of salvation.

Together with His personal presence in the sacrament, Christ is present as a anamnesis of His paschal mystery which, in the prayer of the Church, becomes intercessory. The figure of Christ in eucharistic prayers is realized in a twofold aspect of a priest-mediator, who gives Himself as a sacrifice through a minister and through the voice of the Church, and who is a burnt offering given and present in His mystery through sacramental signs. Christ's eternal sacrifice in heaven becomes temporal and current in a sacramental offering of the Church, making mysterious "contemporariness" between Himself and the believers. That is the most appropriate sense of the Tridentine repraesentaretur applied in the decree about the sacrifice of the Mass. ${ }^{26}$

\footnotetext{
${ }^{26}$ The Council of Trent, Doctrine touching the sacrifice of the Mass, chap. 1: DH 1740.
} 


\section{In the Holy Spirit}

The Holy Spirit with His working which is actually not included in the Roman Canon, was clearly appreciated in the new Eucharistic prayers. His role was associated with the change and sanctification of the Eucharistic gifts which later become the source of sanctification of the Church and of individual believers.

In the call addressed to the Father which precedes the consecration -the Epiclesis - the Holy Spirit to whom the transformation of bread and wine is ascribed, is always recalled:

- "Make holy, therefore, these gifts, we pray, by sending down your Spirit upon them like the dewfall, so that they may become for us the Body and Blood of our Lord, Jesus Christ" (Eucharistic Prayer II);

- "By the same Spirit graciously make holy these gifts..." (Eucharistic Prayer III);

- "May this same Holy Spirit graciously sanctify these offerings..." (Eucharistic Prayer IV).

- The special sharing of the Spirit by the Church and the souls who take part in the Eucharistic sacrifice was additionally emphasised in the intercessory prayer following the anamnesis of the paschal mystery. It bears the features of the ecclesial epiclesis:

- "Humbly we pray that, partaking of the Body and Blood of Christ, we may be gathered into one by the Holy Spirit" (Eucharistic Prayer II);

- "grant that we, who are nourished by the Body and Blood of your Son and filled with his Holy Spirit, may become one body, one spirit in Christ..." (Eucharistic Prayer III);

- "grant in your loving kindness to all who partake of this one Bread and one Chalice that, gathered into one body by the Holy Spirit, they may truly become a living sacrifice in Christ to the praise of your glory..." (Eucharistic Prayer IV).

Therefore, the idea of bestowing the Holy Spirit in the Eucharist recurs in the prayer of the Church: the Spirit who sanctifies the faithful and unites them in the Body of Christ enlivened by the same Spirit. In the Eucharist, ecclesiology opens significantly to pneumatology.

The Trinitarian sense of the Eucharistic Prayer is summarised in the meaningful phrases of the doxology. The prayer of offering and veneration addressed to the Father ("O God, almighty Father"), realizes itself by the power of Christ's mediator ship, in communion with Him and in the ontological immersion in Him ("Through him, and with him, and in him"), and "in the unity of the Holy Spirit". 
This last formula not points to the unity of life existing between the Father and the Son, but also, and above all, to the unity of the Holy Spirit which is carried, experienced and expressed by Christ's Church, enlivened by His breath of life.

This is a developed and coherent scheme which stems from the history of salvation: sacrifice and veneration are given to the Father; Christ is a mediator who, in the ministry of the Church, offers Himself and the faithful who are in communion with Him; the Holy Spirit unites His believers into one Body, joins them with Christ and in this way leads them to the Trinity as a living sacrifice of glory. Eucharistic prayer built on such a foundation expresses internal consistency of the mystery of salvation which central element is the ongoing "circulation": it begins in the Holy Trinity and comes back to It. The communion of the faithful offers itself as a spiritual sacrifice in Christ. The entire humankind, present mystically in the Church, returns to the Father in Jesus Christ who redeemed it through His sacrifice and constantly sanctifies it via his eternal Spirit (cf. Hebrew 9:14).

\section{The communion with the Trinity in Christ}

The grace of the Eucharist realizes itself completely in the sacramental communion, which is the fullness of participation engendering the wonderful unity with Jesus Christ and with the whole Church. A personal encounter with Christ in the reality of His mystery of the Word made flesh, who died, rose and was exalted, is the purpose of the Eucharistic communion, but His presence in a believer is dynamic in character: it is aimed at their sanctification, makes them similar to Christ and leads them to a gradual change through the participation in the mystery of Christ's life, death and resurrection. The transient presence of Christ, connected with the Eucharistic species of bread and wine, is extended in a gift which is the Holy Spirit, whose presence is not connected with any of the terrestrial elements. Christ's Spirit, who maintains unity with Him in the most spiritual way, pours out from His glorious humanity and concurrently brings everyone together into one Body enlivened by a single breath of life. According to a pertinent statement by Heribert Mühlen, the Holy Spirit is "one Person in many persons." ${ }^{27}$ Therefore,

${ }^{27}$ Cf. H. Mühlen, Una Mystica Persona. Die Kirche als das Mysterium der Identität des heiligen Geistes in Christus und den Christen. Eine Person in Vielen Personen, München 1967; A. Czaja, Jedna osoba w wielu osobach. Pneumatologiczna eklezjologia Heriberta Mühlena, Opole 1997. 
Eucharistic communion is two dimensional at the same time, that is vertical and horizontal.

The communion with Christ in the Holy Spirit, in its vertical dimension, leads to the communion with the Father in whom God's life has its beginning and to which the Spirit of sonship leads, given by the glorious Lord. Thanks to Him the believers become "sons in the Son." ${ }^{28}$ Man joins in and becomes a participant in the Trinitarian life, but he is yet separated from it and he is like a stranger until the Holy Spirit brings the sacramental unity to the true, complete and final existential communion. The sacramental communion is at the same time a gift and an awaiting of the Trinitarian participation in faith and love. Together with Christ and in the unity with Him, a Christian speaks, prays and offers himself faithfully to the Father in thanksgiving for being heard and accepted by Him; they feel that according to the promise which was given, the Holy Spirit was granted to them for their sanctification. However, they still await the fulfilment of their unity with God, and for this reason they are encouraged to make the communion with the Trinity the aim of their lives, to the limits of human abilities. Jesus's prayer: "I in them and you in me - so that they may be brought to complete unity" (John 17:23), attains its existential apogee in the eucharistic communion.

In its horizontal dimension the Eucharistic communion and the unity with the Holy Trinity provide a believer with the true sense of the fellowship in the Church; it is a fellowship of the great human family which finds its root in the Trinity which on the other hand assigns this family with a mission, sets out its existential aim and supports it in pursuing this goal. The Trinitarian universal plan of salvation enlightens the relations of a believer with the community of believers and with all other people. A Christian who takes the Holy Eucharist not only unites with the Holy Trinity but also, radiating the virtues of faith, hope and love, becomes the epiphany of the Trinity in the world. St. Augustine mentioned this issue recurrently and distinctly stated that: "If you see charity, you see the Trinity - Immoverovides Trinitatem, sicaritatem vides." ${ }^{29}$ This is the way by which a Christian should give testimony of the saving love of the Father, magnanimous offering of Jesus Christ and sanctifying mission of the Spirit. The Eucharist becomes the sacrament of the communion with the Holy Trinity with all abundance of its aspects, the sacrament of giving of the Trinitarian life

\footnotetext{
${ }^{28}$ The Second Vatican Council, Const. Gaudium et spes, 22.

${ }^{29}$ St. Augustine, De Trinitate 8, 8, 12.
} 
in Christ, the place of meeting of the faithful and the Church united through Christ with the Father and with the Holy Spirit with the dynamism of testimony of the Trinitarian Economy of Salvation in the lives of particular believers, so that everything that came from the Trinity would return to It.

\section{Bibliography}

Alonso Schökel L., L’Eucaristia, Milano 1988.

Augustine, De Trinitate: PL 42.

Augustine, In Ioannis Evangelium tractatus: PL 35.

Balthasar H. U. von, Duch chrześcijański, tłum. Z. Włodkowa, Paris 1976.

Bernadot M.-V., De l'Eucharistieà la Trinité, Paris 1919.

Bobrinskoy B., Communion du Saint-Esprit, Abbaye de Bellefontaine 1992.

Carle P. L., Le sacrifice de la Nouvelle Alliance. Consubstantiel et transsubstatiation. De l'Incarnation à l'Eucharistie, Bordeaux 1981.

Corbon J., Les lieux de communion. Liturgie et oecuménisme, Paris 2009.

Cyril of Jerusalem, Katechezy przedchrzcielne i mistagogiczne, tłum. W. Kania, Kraków 2000, p. 340 (Biblioteka Ojców Kościoła, 14).

Czaja A., Jedna osoba w wielu osobach. Pneumatologiczna eklezjologia Heriberta Mühlena, Opole 1997.

Ferraro G., Il Paraclito, Cristo, il Padre nel quarto Vangelo, Città del Vaticano 1996.

Giraudo C., Eucaristia per la Chiesa. Prospettive teologiche sull'eucaristia a partire della «lex orandi», Roma-Brescia 1989.

Glaeser Z., Eucharystia jako wydarzenie w jedności Ducha Świętego, in: Wspólna Eucharystia-cel ekumenii, ed. P. Jaskóła, R. Porada, Opole 2005, pp. 253-264 (Ekumenizm i Integracja, 12).

Jankowski A., Biblijna teologia przymierza, Kraków 1997.

Kilmartin E. J., Christian Liturgy: Theology and Practice. I. Systematic Theology of Liturgy, Kansas City 1988.

Klinger J., Geneza sporu o epiklezę. Eschatologiczny a memorialny aspekt Eucharystii w kanonie pierwszych wieków, Warszawa 1969.

Krajnc S., Spirituality Based on the Liturgy and on the "Liturgy« through Liturgy, „Bogoslovnivestnik" Vol. 78 (2018), No. 3, pp. 797-811.

Léon-Dufour X., Il Pane della vita, Bologna 2006.

Mędala S., Chrystologia Ewangelii św. Jana, Kraków 2001.

Mühlen H., UnaMystica Persona. Die Kirche als das Mysterium der Identität des heiligen Geistes in Christus und den Christen. Eine Person in Vielen Personen, München 1967. 
Raguž I., Trinitarian-Eucharist Thinking about Christian Initiation, "Bogoslovska Smotra" Vol. 79 (2009) No. 3, pp. 537-561.

Rahner K., Schriften zur Theologie, vol. 4: Neuere Schriften, Einsiedeln-Zürich-Köln 1964. Rogowski R. E., Światłość i tajemnica. Z problematyki teologii egzystencjalnej, Katowice 1986. Šaško I., The Eucharist - the Summit in Accession, Permanency in Living the Initiation, “Bogoslovska Smotra" Vol. 79 (2009) No. 3, pp. 523-536.

Schlier H., La fine del tempo, Brescia 1971.

The Council of Trent, Decree touching the Most Holy Sacrament of the Eucharist.

The Second Vatican Council, Constitution Lumen gentium.

The Second Vatican Council, Constitution Gaudium et spes.

The Second Vatican Council, Decree Presbyterorumordinis.

Tillard J.-M.-R., L'Eucharistie et le Saint-Esprit, „Nouvelle Revue Théologique” 100 (1968) pp. 363-387.

Tillard J.-M.-R., Chair de l'Église, chair du Christ. Aux sources de l'ecclésiologie de communion, Paris 1992.

Thomas Aquinas, Summa theologiae.

Triacca A., Lo Spirito Santo nella liturgia e nella vita della Chiesa, Città del Vaticano 2011.

Valentini D., Lo Spirito Santo. La Chiesa e l'uomo. Studi di ecclesiologia e di ecuemnismo, Roma 2017.

Wieczerza Mistyczna. Anafory eucharystyczne chrześcijańskiego Wschodu, selection, translation and footnes H. Paprocki, Warszawa 1988.

Wolff H. W., Antropologia dell'Antico Testamento, Brescia 1993. 